\title{
Articles
}

Central European Review of Economics \& Finance

Vol. 20, No. 4 (2017), pp. 17-34. D0I: 10.24136/ceref.2017.015

Iwona Kowalska ${ }^{1}$

\section{CONTROVERSY OVER THE ALGORITHM OF DISTRIBUTION OF THE SCHOOL EDUCATION COMPONENT OF THE GENERAL SUBVENTION}

The school education component of the general subvention is the transfer of funds from the state budget to local self-government units in order to supplement their own income. The algorithm for the distribution of these funds, annually established by the Minister of National Education, creates legal and financial controversy in local self-government environment. The calculations based purely on algorithmic distribution of available public funds seem to be an inadequate form of financial planning especially when confronted with the development of finance as a discipline. Therefore, the aim of this article is to assess the construction of the algorithm for the distribution of the school education component of the general subvention with regard to three aspects, which have not been widely discussed:

1. Algorithm and financial security of the systemic changes in education;

2. Algorithm and indebtedness of local self-government units;

3. Algorithm and the unconstitutional rule of earmarking the funds transferred as the school education component of the general subvention to a specific goal.

JEL Classification Codes: H7,G2, I2

Keywords: finance, subvention, education, algorithm, local self-government.

\section{Introduction}

The functions carried out by local self-government units (LGUs) can be classified into four main categories, i.e.: technical infrastructure, social infrastructure, public order and safety, spatial order and planning and conserva-

\footnotetext{
${ }^{1}$ Associate Professor PhD., Warsaw University of Life Sciences, Department of Economics.
} 
tion and ecology (Niewiadomski, 2001). Fulfilment of these functions requires financial resources. According to the European Charter of Local Self-Government financial resources of local self-government units should correspond to the actual costs associated with the exercise of their powers (Journal of Laws of the Republic of Poland, abbreviated Dz. U. 1994 vol. 124, item 607). However, currently the public funds are distributed according to a complex formula in the form of three main funding sources: the central government subvention, subsidies and LGUs' own revenue. Nowadays, the maintenance of the calculations based purely on algorithmic distribution of available public funds seems to be an inadequate form of financial planning especially when confronted with the development of finance as a discipline. The need to go beyond the established schema can also result from the fact that the discipline of finance uses, almost exclusively, methods borrowed from other fields of science and disciplines. Firstly, there are possibilities offered by financial mathematics (the historically shaped and applied methods based on interest calculations, discounting and analyzes based on an arithmetic or geometric progression are now supplemented by new financial instruments, contracts and the dynamic development of futures markets, money markets and exchange markets) (Podgórska, Klimkowska, 2013), secondly, there is a considerable contribution by legal science, sociology, psychology, other social sciences and finally - technology sciences (Szambelańczyk, 2014). A suitable example is the algorithm for the distribution of the school education component of the general subvention. The formula has been creating financial and legal controversy in the local self-government since year 2000, when it was first implemented. The aim of this article is to assess the construction of the algorithm for the distribution of the school education component of the general subvention with regard to the three following aspects: 1. Algorithm and financial security of the systemic changes in education;

2. Algorithm and indebtedness of local self-government units;

3. Algorithm and the unconstitutional rule of earmarking the funds transferred as the school education component of the general subvention to a specific goal.

The system of funding education (which is the priority investment in human capital within the framework of knowledge economy), as a vital element of the public finance system and, more broadly, the entire financial system, deserves a revision of the existing doctrines of public finance associated, on the one hand, with the liberal financial concepts and, on the other hand, with the orthodox theory of public finance (see Owsiak, 2005). 


\section{Construction of the algorithm for the distribution of the school education component of the general subvention}

School education component of the general subvention transferred from central government to local self-government units constitutes the major educational expense incurred by the state budget. Therefore, it determines the amount of funding that local self-governments receive from the state budget for the implementation of educational tasks. The schools grant is not ring-fenced (earmarked to a specific goal), which allows local self-governments to decide on the allocation of funds from this source. However, the same fact results in the inability of local self-governments to acquire additional funds when the amount of the received subvention proves insufficient in relation to the actual cost of implementing educational tasks in the local self-government units (Constitutional Court, Judgement of 18 September 2006. K 27/05). According to article 27 of the Local Self-Government Income Act of 13 November 2003, (Dz. U. 2016, items 198, 1609 and 1985) the school education component of the general subvention for all local selfgovernment units shall be annually determined in the Budget Act. According to article 28 of the cited Act, the amount of funding constituting the school education component of the general subsidy for all local self-government units $^{2}$ shall be equal to the total amount of the school education component of the general subsidy and not lower than adopted in the Budget Act for the given year, corrected by the amount of other expenses arising from changes in the performed educational functions. The formula for the distribution of the school education subvention is defined in the Regulation of the Minister of National Education concerning the distribution of the school education component of the general subvention across local self-government units in a given year. The content of the regulation is subject to annual amendments. In such conditions local self-governments find it difficult to develop long-term financial plans regarding school education provision. The Annex

\footnotetext{
${ }^{2}$ The final amount of the school education component of the general subvention for individual local government units are determined on the basis of statistical data concerning the number of: 1. Teaching positions for each grade in teachers' professional advancement scheme, as evidenced in the Education Information System (on 30 September and 10 October of the previous year) verified and confirmed by the authorities governing schools and education institutions.

2. Pupils in the current school year, reported in the Education Information System (on 30 September and 10 October of the previous year), verified by the authorities governing schools and education institutions.
} 
to the Regulation includes a distribution algorithm for the school education component of the general subvention. It determines the division of public funds in accordance with the following formula:

$$
\mathrm{SO}=\mathrm{SOA}+\mathrm{SOB}+\mathrm{SOC}
$$

The meaning of the symbols is explained below:

So - school education subvention, after deduction of the reserve, referred to in article 28, section 2 of the Local Self-Government Income Act of 13 November 2013.

SOA - the base amount of the school education subvention according to the financial standard ' $A$ ' of the division of the school education component of the general subvention dedicated to the implementation of school tasks; SOB - the supplementary amount of the school education subvention calculated in accordance with ' $P$ ' weightings which increase the financial standard 'A' dedicated to the implementation of school tasks;

SOC - the amount of the school education subvention dedicated to the implementation of out-of-school tasks.

The key element of the breakdown of the amount of the school education component of the general subvention for the financial year is financial standard 'A' per-pupil, modified by the weightings system (depending on the type of educational task) and a modifying index taking into account the grades of teachers' professional promotion 'Di'). Financial standard of the division is obtained by dividing the total amount of the subvention (after deduction of the reserves) by the total number of pupils. This provision does not correspond to the provisions of the cited Regulation indicating that the allocation of the general subvention to local self-government units shall take into account the following functions:

1. Funding of current expenditures of schools and institutions run by local self-governments related to:

- Teachers: salaries and derivatives; professional advancement training; granting paid leave for health reasons; severance pay $^{3}$; remuneration to apprenticeship supervisors, social benefits for pensioners; salaries of teachers involved the oral part of the matriculation examination; costs

\footnotetext{
${ }^{3}$ According to article 20 of Teacher's Charter the school director has the right to terminate the contract of employment with a teacher in case of total or partial liquidation of the institution, and in the case of organizational changes causing a reduction in the number of classes in the school or changes to the curriculum which prevent further recruitment of teachers.
} 
of the examination commission granting professional advancement grades to teachers);

- Pupils: individual teaching; education of students who are not Polish citizens; early support of child development; equipment for health care and first aid facilities; career advising services.

2. Subsidizing schools and institutions run by legal entities other than local self-governments and by natural persons.

It is not possible to determine the cost of implementation of the abovementioned tasks i.e. to execute from the state budget such number of financial standards 'A' to cover e.g. current expenditure on school education provision. If the algorithm took into account standard costs of education services (including teachers' employment standards) (see Kowalska, 2010) the allocated funding would be more adequate to the actual needs of local self-governments. To sum up, the algorithm is presented as a formula which ensures that money follows a pupil while in reality it is not a pupil but a class which generates costs for local self-governments.

\section{The algorithm for the distribution of school education component of the general subsidy and funding needs of local self-governments in the perspective of education system reform}

According to Education Act of 14 December 2016 (Dz. U. 2017, item 59) and the regulations implementing the Education Act (2017, item 60) the school system will be transformed. The current system comprises: 6-year primary school, 3-year lower-secondary school (gimnazjum), 3-year upper-secondary school (liceum), 4-year upper-secondary vocational school, 3 -year basic vocational school and post-secondary non-tertiary school. The new system of education will comprise: 8-year primary school, 4-year secondary school (liceum), the 5-year secondary vocational school, 3-year lower secondary industry-school, 2-year-old higher secondary industry secondary school, 3-year special vocational school for pupils with disabilities and post-secondary non-tertiary school Lower secondary schools will gradually be phased out starting from the school year 2017/2018. In this year and the coming years recruitment to these schools will no longer be conducted. Starting from 1 September 2019, secondary schools will no longer exist in the school system.

The question that should be asked here is if the algorithm for dividing the school education component of the general subsidy addresses the needs for 
funding which local self-government units have in connection with the implementation of the reform of the school system. In the justification of the Regulation of 22 December 2016 concerning the distribution of the general subvention to local self-government units in 2017 (Dz. U. 2016, item 2298) the Minister of National Education presented a line of argument which cannot be accepted. The argument suggest that because of the increase of school starting age (from 6 to 7 years) the amount of the school education component of the general subvention in 2017 should be reduced by the amount of 1449473 thousand PLN as the scope of education tasks fulfilled by local self-governments and covered by the subsidization has decreased. In fact, the amount earmarked to this goal in the draft state budget for 2016 was 1204000 thousand PLN which represented a difference of nearly 250 million PLN. The excess amount could be used by local self-governments to cover organizational changes in schools and education institutions. However, it should be noted that the excess amount does not include the majority of 7 -year-old pupils who do not repeat the first grade and start the second grade. Consequently, the funding earmarked to cover the costs of the education system reform is lower than the amount of 250 million PLN. The budget for 2017 does not specify the number of seven-year-old children who will begin compulsory schooling in the next financial year. The absence of this figure makes it impossible to determine if the reduction of the school education component of the general subvention by the abovementioned amount is adequate. Therefore it cannot be concluded that the increased funds for this purpose will fully cover the local self-governments' expenditure on organizational changes in schools and education institutions. Projected number of statistical pupils determines the number of pupils used for calculations, which in turn has direct effect on financing various educational tasks (Opinion of the National Section ..., 2016).

Another important issue related to the transformation of the education system is financial coverage of teachers' layoffs resulting from the reform. Local self-governments expected that funding for this purpose will be included in the algorithm for the distribution of the school education component for the year 2017. However, the Ministry denied the fact that the implementation of the school reform would lead to layoffs of teachers. Thus, the algorithm does not include any funding factor that would directly relate to this purpose. However, it can be argued that as a result of the liquidation of lower secondary schools and the introduction of 8-year primary school municipalities will provide education services for 8 not 9 grades of pupils (approx. 357 thousand 
pupils less). According to the calculations made by the Polish Teachers' Union (ZNP) the amount of school education component of the general subvention which municipalities will receive to maintain the same number of buildings and teachers in 2017 will be approximately 1.89 million PLN smaller. This is the equivalent of the salaries of approximately 37 thousand teachers (in the school year 2016/2017 lower secondary schools employed approximately 100 thousand people). Furthermore, according to the law lower secondary school teachers employed by appointment or with unlimited contract of employment, whose further employment in the school year 2017/2018 will not be possible due to the organizational changes resulting from changes in the structure of the schools, will be granted the 'inactive' status or their employment contracts will be terminated at the end of the school year. Teachers who have been granted the 'inactive' status will receive a salary for six months. This is a hidden cost of the reform for local self-governments, because the municipalities will have to pay these salaries without any additional funding secured from the central budget. After this period of time the employment status of teachers who do not get a job in another school will automatically terminate. Also, it should be emphasized that the 'inactive' status can only be granted to appointed teachers or those with unlimited contract of employment. Those teachers who are employed on fixed-term contracts (mostly young teachers) probably will not have the contract prolonged and if they do not get a new job (regardless of industry) they will become unemployed. Consequently, the municipalities' expenditures on social welfare will increase. According to the Ministry of National Education, in the transition period the teachers with 'inactive' status will have the priority to fill available vacancies. However, the new secondary schools which gained additional grade (year) and in theory could employ teachers from the lower secondary schools, each year lose approx. 30 thousand pupils. This means that even without the reform, one in three teachers employed by the district authorities works parttime. Therefore, when following the reform secondary schools open more classes the head teachers will first add teaching hours to the schedules of the already employed teachers to let them work full time rather than recruit new teachers. The shield program involving the ban on teachers' overtime may also increase the costs for the local self-government, (e.g. instead of paying for extra 2 or 3 hours to already employed teachers the authorities will need to employ a part-time teacher which generates costs per person). 


\section{Algorithm for distributing the school education componentof the general subvention and debt limits for local self-government units}

In the algorithm for distributing the school education component of the general subvention costs are calculated per pupil. As a result, the amount of school education subvention may not cover the actual cost of the implementation of educational tasks paid by local self-government units, because the cost is generated by a class and not a single pupil. The missing funds for the implementation of educational tasks may come from local self-governments' own revenue. The revenue comes from four sources: local taxes, property, share in state taxes, income other than grants earmarked to a specific goal or general subvention) (Guziejewska, 2008). Also, local self-government funds are public revenue and the power to define it is constitutionally reserved for the law. Local self-governments are not entitled to enact law regarding their revenues. They have only the power to modify the rates to the extent provided by the existing law (e.g. grant a relief, set a lower rate, debt remission) (Kosikowski, Salachna, 2012). Naturally, municipalities in Poland have diverse budgets. The indicators of tax revenue per capita (index G) for 2015 show that the income of the richest municipality in Poland - Kleszczów (34 825.79 PLN), is more than 80 times higher than the tax revenue of the poorest local self-government Radgoszcz (424.77 PLN). The national average can be represented by Czestochowa, where tax revenue per capita is 1597.53 PLN (Ranking of Municipalities 2017). The missing amount of funding can be obtained from external sources or by incurring financial obligations. But local self-government debt limit is regulated by art. 243 of the Public Finance Act of 27 August 2009. (Dz. U. 2013.885; 2016.10.01; Dz. U. 2016.1454). Thus, local self-governments which lack funding will have the dilemma of how to acquire funds and not exceed the statutory debt limits. The flaws in the algorithm of the division of the school education subvention (financial standard 'per-pupil') can contribute to yet another negative phenomenon - local self-governments may be tempted to bypass debt limits, imposed by the Public Finance Act, and use non-standard debt instruments. The use of non-standard instruments is fostered by the pressure connected to the implementation of EU investments (including investments in education) under EU programming for 2014-2020 ${ }^{4}$ combined

\footnotetext{
${ }^{4}$ In the programming period of the EU for the period 2014-2020 local governments will receive about 100 billion PLN, 65 billion of which will come fromf the Regional Operational Programmes.
} 
with the limited possibilities of local self-governments to take out loans, credits and issue securities.

Non-standard debt instruments are not forbidden. They are endorsed in the Regulation of the Minister of Finance of 28 December 2011 concerning the detailed method of classification of debt instruments classified as public debt (Dz. U. 2011 vol. 298, item 1767) which includes catalogue of debt titles evidenced as state public debt. Local and regional authorities use different methods to bypass the statutory rigors concerning debt:

1. Concluding apparent debt takeover and debt restructuring agreements. In essence, with regard to their content, they may be classified as loan or credit contracts or unnamed agreements of the same nature because there is no entry of a third party (a bank or financial institution) in the position of the creditor to the amount of the incurred payment (in the analyzed cases, the third party was not entitled to the same receivables the original creditor).The agreements were not concluded in order to acquire the creditor's rights, but to make a profit (interest rate, commissions). These agreements were not less burdensome for the debtor (local self-government units). In relation to the original debt they did not offer e.g. a shorter repayment period or lower interest rates. In addition, the local self-government unit was obliged to pay additional fees to the new creditor (bank, financial institution), such as interest rate, commission and debt restructuring commission. The agreements extended the time limit for credit repayment compared to the original creditor's terms and secured the return of the amount of credit to the bank or financial institution in the form of a blank promissory note.

2. Factoring agreement. According to the so-called. Ottawa definition a factoring company performs at least two of the following actions:

- Finances undisputed and undue receivables;

- Keeps records of accounts receivables;

- Enforces claims;

- Takes the risk of customer solvency (Filipiak, Zioło, 2016)Under such agreements, the factor (bank) agrees not to collect its receivables from the debtor after the expiry of the repayment date as specified in the VAT invoices (as a rule, the debtor should pay the due amount within the period specified on the invoice and after expiry of the term the creditor should take steps to enforce the receivables) and the debt will be repaid in the new repayment period, which is extended by a few years in relation to the payment terms specified in the invoices. In exchange for the extension of time limit for debt repayment and the bank's commit- 
ment not to enforce the debt the borrower has to pay interest calculated from the due date (the date indicated in the invoice) to the repayment date (new deadline for payment of debts agreed between the parties in the payment schedule annexed to the agreement) These agreements are essentially new credit agreements or agreements of a similar nature. In fact, in factoring the role of a debtor does not change. As a rule, the debtor should only repay the debt to the new creditor.

3. Other pseudo-financial products displaying the characteristics of refundable financing instruments like subrogation, sellback and leaseback. These instruments involve complex legal and financial structures, which differ from classic loans and securities because they are not subject to statutory limitations with regard to their content (purpose), obligation to acquire appropriate opinion of the supervisory authority or meeting statutory debt limits.Subrogation involves two parties - a financial institution pays off the debts of local self-government unit and is entitled to enforce its receivables while a new repayment schedule is agreed. The financial institution does not aim to take the rights of the creditor, but to create a new legal relationship, (in particular regarding the terms and conditions of debt repayment by the local self-government unit). From the economic perspective, the transaction is similar to taking out a loan by the local self-government to meet specific obligations (repay debt to former creditor). In the local self-government's budget the repayment to a financial institution is recorded as current expenditure or property expenditure, depending on the nature of the receivable. This option is not included in the provisions of Public Finance Act (art. 243) and should be treated as debt title (Regulation of the Minister of Finance on the specific method of classification of debt instruments classified as public debt, sec. 2, subsec. 2). But subrogation of debt pursuant to the Civil Code (art. 518, sec.1, subsec. 3) permits the repeated incurring of debt (Kluza, 2015).

- Sellback - involves a purchase of property (land, developed land) by a financial institution, from a local self-government while at the same time both parties conclude a preliminary purchase and sale agreement whereby the local self-government undertakes to purchase the property back at the sale price Up to this date the property is owned by a financial institution and leased to the local self-government unit, e.g. on the basis of a lease agreement. The sales-back involves three agreements (purchase and sale contract, lease contract and preliminary purchase and sale contract). The seller of the property gets rid of a tangible asset in exchange for financial assets and still retains exclusive rights to 
dispose of the property. The buyer receives the right to collect benefits from the lease of property and resigns from the owner's right to dispose of the property in return for rent paid for the entire period until the retransfer of ownership Thus, from the initial sale until the repurchase the seller does not lose control over the property and the buyer receives rent together with a guarantee of repurchase. Neither party is actually interested in buying or selling the property (transfer of ownership), but only the cash flow resulting from the exchange of assets. Therefore in such cases it is groundless to perceive these purchase and sale or lease contracts as classic civil law contracts. When used in a package, they form the instrument for trading monetary assets, based on the return transfer of ownership. In this context, the applied solution becomes an instrument of financing analogue to a loan referred to in article 89 and article 90 of the Public Finance Act. The analysis of the described operations leads to the conclusion that its real purpose is taking out a loan by local self-government unit where the selling price is income, the lease rent is the cost of debt service and the purchase price of the property is repayment of the loan (Report on the activities..., 2015).

- Leaseback involves debt financing, based on mutual transfer of property rights in order to release capital without prejudice to existing rights to use the assets (sale of an asset and the simultaneous acquisition of this asset under a lease contract) (International Financial Standard 17, Leases. Official Journal of the European Union, 29 Nov. 2008 L 320/83, Westerfield, Jaffe, 1999). By entering into a lease agreement the financing party undertakes to buy an asset from a specific vendor under the terms of the agreement and then provide it as a leasing subject to the lessee for a defined period of time while the lessee agrees to pay the lessor a rent in agreed instalments and the total of rental payments should at least be equal to the original price the lessor paid for the asset. In order to fulfil the definition of leaseback the vendor of an asset and the lessee should be the same entity The agreement provides for the return transfer to the vendor after the period for which the contract was concluded.

The use of these non-standard debt instruments usually has a different effect than the local self-governments would expect. The contracts, which in nature are credit agreements or contracts of a similar nature should be evidenced as the public debt. The fact that local self-governments do not include their actual receivables restructured with the help of non-standard financial instruments in the calculation of debt index results in the increase in 
their actual debt, leading to a situation in which they may not be able to adopt the Multi-Annual Financial Forecast (WPF) or budget in accordance with the rules referred to in articles 242-244 of the Public Finance Act. To sum up, the use of non-standard debt restructuring instruments is dangerous, because the phenomenon significantly distorts data reflecting the financial situation of local self-governments. In extreme cases the local self-government may be compelled to adopt a rehabilitation program or the budget is adopted by the Regional Chamber of Audit. The report of Regional Chambers of Audit: "Non-standard financing instruments and budgetary needs of local self-government units" published in 2016 shows that the liabilities of local self-government units amount to a total of 274.5 million PLN (including the original debt and any payments incidental to the instrument, e.g. the rental payments, interest, fees, lease payments, deposits on account of the repurchase, etc.).

Regional Chambers of Audit identified a group of local self-governments, which were in danger of losing liquidity, or have lost liquidity. The analysis of data from Multiannual Financial Perspective (WPF) aggregated from the reports on meeting obligations, a statutory instrument of control and monitoring of debt (in force from 2014), showed that in the years 2015-2018, hundreds of local self-government units will have little potential to incur new debt obligations in the form of loans, credits and securities. When formulating such opinions Regional Chambers of Audit take into account the methodology of Multiannual Financial Perspective developed by the Ministry of Finance according to which the essence of the assumptions made in the development of this document should be based on how much money a local self-government has, and not how much they need (Sołtyk, Dębowska-Sołtyk, 2016). In the opinion of Regional Chambers of Audit is necessary to extend the catalogue of debt titles by including unnamed contracts having an effect equivalent to a loan or credit agreement.

\section{The algorithm for distribution of the school education component of the general subvention and the unconstitutional rule of earmarking funding transferred as part the grant to a specific goal}

Algorithm and the unconstitutional rule of earmarking money transferred as part the schools grant to a specific goal is an issue which can be illustrated by the example of the Budget Implementation Act 5 December 2014 amending certain acts in connection with the implementation of the Budget Act (Dz. U. item 1877). The abovementioned act states that, from 1 January 
2015 funding allocated by local self-governments to education of pupils with special educational needs (SEN) should not be lower than the amount calculated for these tasks in the school education component of the general subvention. According to article 32 of the cited Budget Implementation Act in 2015 funding for tasks that require special organization of learning and working methods for children and young people has to be allocated in the amount not smaller than the amount resulting from the division of the general subvention for local self-government units. These provisions of the Budget Implementation Act followed the interventions of the Government Plenipotentiary for the Disabled who reported that the funding from school education subvention does not reach students with disabilities, but serves other goals. This seemed to be a real problem as the funding per pupil with special educational needs can be much higher than the standard per pupil rate. Pupils with disabilities attract additional amount of funding from the subvention depending on the type of disability: even 9.5 times the basic per pupil funding rate (e.g. a pupil with multiple disabilities could attract even 50 thousand PLN per year). This supplementary amount called conversion weighting is calculated on the basis of a statement of special educational needs held by a pupil. Therefore new budget classification sections have been created to evidence expenditure in this area:

1. 80149 - Implementation of the tasks requiring special organization of learning and working methods for children in preschools, preschool classes in primary schools and other forms of pre-school education;

2. 80150 - Implementation of the tasks requiring special organization of learning and working methods for pupils in primary schools, lower and higher secondary schools, vocational secondary schools and art schools.

The Ministry of Finance stressed that education of children and young people with SEN requires a correspondingly higher funds, which are secured in the algorithm for the distribution of the school education subvention for a given year by weighting the formula factors. It is therefore appropriate to expect local self-government units to allocate funds in the amount not lower than the amount resulting from the division of the general subvention. The Ministry of Finance also argued that local self-governments and schools under their governance should maintain separate evidence of expenditure on education of children and young people who require special organization of learning and working methods, in particular pupils with disabilities. Even though the Ministry's arguments cannot be easily dismissed critical voices arose undermining the usability of the budgetary classification (negligible cognitive value regarding processes associated with the allocation of public 
funds, low legibility, generic character, lack of focus on results, not applicable in effective and efficient public finance management) (see Heciak, 2014). When the Ministry of Finance planned to alter budget classification they took into account the results of the report of the Supreme Audit Office (NIK). The NIK report from 2012 followed an inspection of school governing bodies. The report showed that 19 percent of the inspected local self-governments have not used 100 percent of funding (from the school education component of the general subvention) earmarked to the education of pupils with disabilities. Although the report also showed that in the case of 62 percent of local self-governments the amount of funding allocated to the education of pupils with special needs exceeded the amount of the granted subvention and 19 percent of self-governments spent exactly the amount granted as school education subvention.

Local self-governments do not question the necessity of allocating higher funding to educating pupils with disabilities. However, the changes, (introduced in 2015), in settling the school education subvention dedicated to pupils with SEN needs were rated as doubtful with reference to local authorities' financial independence and systemic changes in local self-governments. The changes in providing education for pupils with disabilities have turned the school education component of the general subvention into yet another grant (subsidy) from the state budget. The way school education subvention is supposed to be settled is incompatible with article 7 sec. 3 of the cited Local Self-Government Income Act. In the case of the general subvention - including the school education part of the general subvention - it is the governing body of the local self-government unit who is in power to decide about the funding destination. There are two important differences between a subvention (including school education subvention) and a subsidy (grant):

1. Subvention as opposed to subsidy (grant) is a legal claim and is not subject to any settlement (nor any conditions) - the decision as to its distribution, is taken by the authority that received it. Therefore, a condition included in the text of article 32 of the Budget Implementation Act is inconsistent with the definition of a subvention and therefore inconsistent with the provisions of the Local Self-government Income Act.

2. This distinction is reflected in doctrinal definitions of the general subvention. The general subvention is a transfer of funds from the state budget to local self-government budgets and it is general in character, non-refundable, unpaid, not subject to any terms and is meant to support their own revenue. Only the governing bodies of local self-government units are in power to decide about the allocation of this funding. While the subsidy 
according to Polish financial law means the transfer of funding earmarked to goals strictly defined by law. The term 'subsidy' is used when an entity is supported with funding from public resources transferred from a budget or special purpose fund (Lachiewicz, Legutko, Winiarz, 2006). Etymologically the Polish term dotacja (subsidy) is derived from the word dotatio which means providing someone with material goods ( Lachiewicz, 2010).

Changes provided in art. 32 of the Budget Act are also considered questionable in the context of compliance with article 32, sections 1 and 2 of the Constitution (Dz. U. 1997 vol. 78 item 483).

Regardless of the problem of earmarking the funding for local self-governments to a goal (ring-fencing), the settlement of the school education component (consistent with the principle that funding amount spent on education of pupils with SEN should not be lower than the amount resulting from the division of the school education component of the general subvention) required addressing the following issues:

1. Can local self-governments allocate funding as they wish, i.e. in such a way that the amount of funding for the implementation of the abovementioned tasks was not lower than the amount granted as the school education component of the general subvention or should they include the funding in separate financial plans of each of the institutions they govern in accordance to the weights subscribed respectively to each unit?

2. Should the sum of financial plans (sections 80149 and 80150 ) be equal to the sum of the weights from the school education subvention, or should this sum include other budget sections, e.g. 80102, 80105, 80111?

3. Does the introduction of new budget sections result in the transfer of plans from such sections as 80105 (Special Preschools), 80102 (Special Primary Schools), 80121 (Special Secondary Schools) to sections 80149 and 80150 ? Could this mean that such sections as 80105 (Special Preschools), 80102 (Special Primary Schools) will not function?

4. When settling the school education component of the general subvention, should only two new sections (80149 and 80150 ) be taken into account or also other sections like e.g. 85406 (Counseling Centers)?

5. What are the penalties for local self-governments for failure to allocate funding in the amount required by regulations? It can be argued that in such case the local self-government would breach the discipline of public finances (understood as acting in compliance with legal norms defining the rules of acquiring and spending public funding applicable to all entities disposing of public finance) (Ziółkowska, 2012). 
The proof of compliance with the requirements of article 32 of the Budget Implementation Act was the amount of planned budget expenditures of local self-government units and their implementation (spending) under the new sections 80149 and 80150 , but also plan and implementation of the budget of local self-government units related to the abovementioned school education component of the general subvention under the previously existing sections: $80102,80105,80111,80121,80124,80134$.

During the financial year local self-governments were obliged to revise their budgets and evidence their costs in the existing and new sections. The most significant item was personnel costs. The cost extraction was not difficult for teachers who are employed exclusively in connection with the special organization of education for pupils with special needs, but problems arose in the case of teachers whose responsibilities include both special and standard teaching. It was even more difficult to estimate the costs of electricity, heating or water per pupil with special educational needs educated in an institution for a longer period of time. Another problem was to calculate the costs of providing special education to pupils attending mainstream classes, where the pupil with SEN is granted a certain number of extra hours, often with different teachers who deliver only a number of hours of special teaching alongside standard teaching. Due to the planned reform of the education system from 1 September 2017 the work on the changes in the way the school education component of the general subvention is settled and evidenced will be continued, because once again local self-governments will be obliged to use different budget classification under the heading: 801: Education and Upbringing (section 80111 - special lower secondary schools will not function due to the phasing out of this type of school).

\section{Summary and Conclusions}

The conducted analysis of the algorithm for distribution of the school education component of the general subvention with regard to the aspects mentioned in the introduction showed that:

1. The algorithm does not secure funding for the planned changes to the system of education (the cost which local self-governments will have to bear to implement the school system reform);

2. When the funding for the provision of public education tasks by local selfgovernment units is not secured, local authorities may be determined to acquire the missing funds from the market by taking out loans. However, in 
order to bypass debt limits local self-governments reach for non-standard debt instruments that actually increase their actual debt;

3. The allocation of school education subvention can be evidenced with the violation of the principle according to which funding transferred as part of the general subvention should not be earmarked to any specific goal (ring-fenced), which makes it identical with a subsidy.

These conclusions could provide a ground for discussion about changes to the way in which funding for school education is distributed and evidenced in Poland. The results of these analyzes could be presented at consultation workshops organized by the Ministry of National Education on the calculation methods to determine the total amount of school education subvention and the principles of its division. However, these workshops are dedicated mainly to representatives of local self-governments, governing bodies of schools and education institutions, head teachers and school superintendents. Unfortunately, the representatives of the scientific community are not invited. The contribution of the latter could enrich the discussion by providing research results on the economics of education in order to see the inevitable cause and effect relationships between educational finances and the whole system of public finance.

\section{References}

Filipiak B. Z., Zioło M. (eds.) (2016). Współpraca jednostek samorządu terytorialnego z instytucjami finansowymi. Difin, Warszawa.

Guziejewska B. (2008). Zewnętrzne źródła finansowania samorządu terytorialnego. Teoria a praktyka. Wydawnictwo Uniwersytetu Łódzkiego, Łódź.

Heciak S. (2014). Finanse i rachunkowość sektora publicznego. Presscom, Wrocław.

Kluza K. (2015). Innowacje finansowe w jednostkach samorządu terytorialnego na skutek wejścia w życie art. 243 ustawy o finansach publicznych. Studia Ekonomiczne. Zeszyty Nukowe Uniwersytetu Ekonomicznego w Katowicach, 238.

Kosikowski C., Salachna J.M. (ed.) (2012). Finanse samorządowe. Wolters Kluwer, Warszawa, p. 252.

Kowalska I. (2010). Finansowanie ze środków publicznych edukacji na wsi. Wydawnictw. SGGW, Warszawa.

Lachiewicz W. (2010). Prawo o dotacjach - zarys systemu po reformie finansów publicznych. In: W. Lachiewicz (ed.), Finanse publiczne. Praktyka stosowania nowej ustawy o finansach publicznych i aktów wykonawczych (p. 431). C. H. Beck, Warszawa. 
Lachiewicz W., Legutko M., Winiarz M. (2006). Udzielanie dotacji z budżetów samorządów ze wzorami dokumentów, komentarzem i orzecznictwem. Municipium, Warszawa.

Niestandardowe instrumenty finansowania potrzeb budżetowych jednostek samorządu terytorialnego (2016). Krajowa Rada Regionalnych Izb Obrachunkowych, Łódź.

Niewiadomski Z. (2001). Samorząd terytorialny, ustrój, gospodarka. Branta, Bydgoszcz - Warszawa.

Opinia Krajowej Sekcji Oświaty i Wychowania NSZZ „Solidarność” w sprawie projektu budżetu państwa na rok 2017 w części oświatowej subwencji ogólnej dla jednostek samorządu terytorialnego oraz kwoty bazowej dla nauczycieli. [Opinion of the National Section of Education "Solidarity” concerning the draft state budget for 2017 and the school education component of the general subsidy to local self-government units and the base amount for teachers.] (2016). Gdańsk.

Owsiak S. (2005). Finanse publiczne. Teoria i praktyka. PWN, Warszawa.

Podgórska M., Klimkowska J. (2013). Matematyka finansowa. Wydawnictwo Naukowe PWN, Warszawa.

Ranking gmin 2017 na podstawie danych podatkowych za 2015 r. według stanu na dzień: 30.06. 2016. [Ranking of Municipalities based on tax revenue data from 30 June 2016] PAP samorząd.

Ross S.A., Westerfield R.W., Jaffe J. (1999). Corporate Finance. Irwin/McGraw-Hill.

Sołtyk P., Dębowska-Sołtyk M. (2016). Finanse samorządowe, Difin, Warszawa.

Sprawozdanie z działalności regionalnych izb obrachunkowych i wykonania budżetu przez JST za lata 2014 [Report on the activities of regional accounting chambers and implementation by the local self-government for the years 2014] (2015). Krajowa Rada Regionalnych Izb Obrachunkowych, Warszawa.

Szambelańczyk J. (2014). Finanse wobec problemów teorii i praktyki bankowości w Polsce. In: J. Czekaj, S. Owsiak (ed.), Finanse w rozwoju gospodarczym i społecznym, PWE, Warszawa.

Wyrok TK z 18 września 2006 r. K 27/05. [Constitutional Court, Judgement of 18 Sept. 2006]

Ziółkowska W. (2012). Finanse publiczne. Teoria i zastosowanie. Wydawnictwo WSB, Poznań. 